\title{
Success Indicators of the Philippine National Aquasilviculture Program (PNAP) - Mangrove Rehabilitation Project in Davao del Sur, Southern Philippines
}

\author{
John Paul Relacion Pacyao ${ }^{1 *}$, Marlyn Bersabe Llameg ${ }^{1}$ \\ ${ }^{1}$ Institute of Fisheries and Marine Sciences (IFMS), Southern \\ Philippines Agri-Business and Marine and Aquatic School of \\ Technology (SPAMAST), Poblacion, Malita, Davao Occidental, \\ Philippines
}

*Corresponding author: John Paul Relacion Pacyao: johnpaulpacyao@gmail.com

\section{Abstract:}

Citation: Pacyao J.P.R., Llameg M.B. (2018) Success Indicators of the Philippine National

Aquasilviculture Programm (PNAP) - Mangrove Rehabilitation Project in Davao del Sur, Southern Philippines. Open Science Journal 3(1)

Received: $6^{\text {nd }}$ May 2016

Accepted: $23^{\text {th }}$ November 2017

Published: $18^{\text {th }}$ February 2018

Copyright:@ 2018 This is an open access article under the terms of the Creative Commons

Attribution License, which permits unrestricted use, distribution, and reproduction in any medium, provided the original author and source are credited.

Funding: The author(s) received no specific funding for this work

Competing Interests: The author have declared that no competing interests exists.

The study was conducted to evaluate success indicators of the Philippine National Aquasilviculture Program (PNAP) - Mangrove Rehabilitation Project in Davao del Sur. The growth increment of mangroves(cm/day) and survival and the physico-chemical parameters of the different project sites were recorded. A questionnaire was employed to gather in socio-demographic profile, best practices employed, benefits and institutional factors. The study employed one shot sampling. The growth increments of mangroves in Punta Biao $(0.0032 \mathrm{~cm} /$ day $)$ was comparable with Bucana $(0.0031 \mathrm{~cm} /$ day $)$ but were significantly higher than the rest of the project sites.Sto. Rosario exhibited the lowest growth increment of $0.0007 \mathrm{~cm} /$ day. In terms of survival, Bucana and Punta Biao showed the highest survival rate of $96.87 \%$ and $99.62 \%$ respectively, while San Isidro obtained the lowest mean value of $13.71 \%$. Two (2) types of area orientation found in the different project sites, midland and tidal/mud flats. Soil types were clay loam and sandy clay. High survival and high growth increment were observed in midland area with clay loam substrate while low survival observed in seaward areas with sandy clay substrate. The $\mathrm{pH}$ ranged from 6.46-7.23 while salinity ranged from 23ppt-35ppt. Some of the contributing factors that influenced higher survival rate of PNAP Mangrove Rehabilitation Project in Davao del Sur include the used of matured mangrove propagates, staking prior to mangrove planting, regular monitoring at least every other day and carefully scraping epiphytes (e.g. barnacles and oysters) during mangrove's early stage. This practices observed in all project sites regardless of percentage rate recorded. 
Keywords: Aquasilviculture, Mangroves

\section{Introduction}

Mangroves is the term used to categorize trees and shrubs that have grown in and have developed morphological adaptations to the inter-tidal environment (e.g. aerial roots, salt excretion glands and vivipary of seeds) and to the ecosystem. Mangroves form a distinctive ecosystem composed of peculiar plants, animals and micro flora and fauna commonly found along sheltered coastlines, shallow-water lagoons, estuaries, rivers or deltas in the tropics and sub-tropics where they perform important socio- economic and environmental functions. A majority of human population who live in coastal areas depend on local resources for their livelihood. The mangroves are sources of highly valued commercial products and fishery resources and also are sites for developing a burgeoning ecosystem. The mangrove forests provide wide range of materials for human sustenance ranging from fuel-wood collection to fisheries. The life of mangrove inhabited coastal areas depends on various goods and services provided by mangroves (Walton et al., 2007).

For the past decades, the Philippine fisherfolks have been experiencing declining fish catch. Many coastal communities are also experiencing displacement due to storm surges in their areas. A major contributor to these problems is the disappearance of our mangrove forests. With this, breeding grounds of fishes were destroyed and the disappearance of natural wave barriers left communities vulnerable to storm surges. In 1995, it was recorded that there were only 117,000 hectares of mangrove forests left from a high of 500,000 hectares a century ago. Mangrove forests have been converted to fishponds, used indiscriminately as firewood and as a resource for housing construction as well as for other uses (Yparraguire, 2008).

For several decades, there has been a drastic decrease in the habitats of mangroves in the Philippines, and together with the warnings of global warming and other environmental destructions, different institutions are investing time and effort to restore the natural environment, the Philippines once had. Bringing back the habitats of mangroves is done by a lot of organizations (Samson and Rollon, 2008).

Massive rehabilitation efforts have been done for the last two decades both by the government, non-government agencies and other concerned sectors but environmental degradation remains to be an alarming issue. This pressures for development and utilization of the coastal resources particularly the mangrove ecosystem. It must be addressed within a realistic framework of conservation and sustainable resource management without jeopardizing the livelihood of the coastal fisher folks. Considering this situation, the Bureau of Fisheries and Aquatic Resources (BFAR) has partnered with the Commission on Higher Education (CHED) for the promotion of Philippine Aquasilviculture, which aims to protect and restore habitats for fisheries and aquatic resources, the establishment of community-based hatcheries, mangrove habitat rehabilitation and conservation, and providing alternative sustainable livelihood to the 
community at the same time empowering them as warden of the ecosystem (Generalaoet al., 2014).

SPAMAST in close coordination with BFAR implemented the mangrove rehabilitation project. The ultimate purpose of this project is to rehabilitate the potential mangrove areas in the province of Davao del Sur and Davao Occidental.

\section{Objective of the Study}

The following were the objectives of this study:

1. To assess the success indicators which were based on plant growth and survival of the different PNAP mangrove rehabilitation project sitesin Davao del Sur.

2. To evaluate the factors behind their PNAP success.

3. To recommend specific protocols in implementing mangrove rehabilitation programs.

\section{MATERIALS AND METHODS}

\section{Study Area}

The study was conducted in nine (9) coastal barangays of Davao del Sur to include Lawa, Don Marcelino, Buhangin, Malita, Sto. Rosario, Sta. Maria, Bagumbayan, Malalag, Balasinon, Sulop, San Isidro, Padada, Bucana, Hagonoy, Punta Biao, Digos City, and in Tagabuli, Sta. Cruz. The identified sites have existing planted mangroves as part of Philippine National Aquasilviculture Program (PNAP) - Mangrove Rehabilitation Project (Fig. 1).

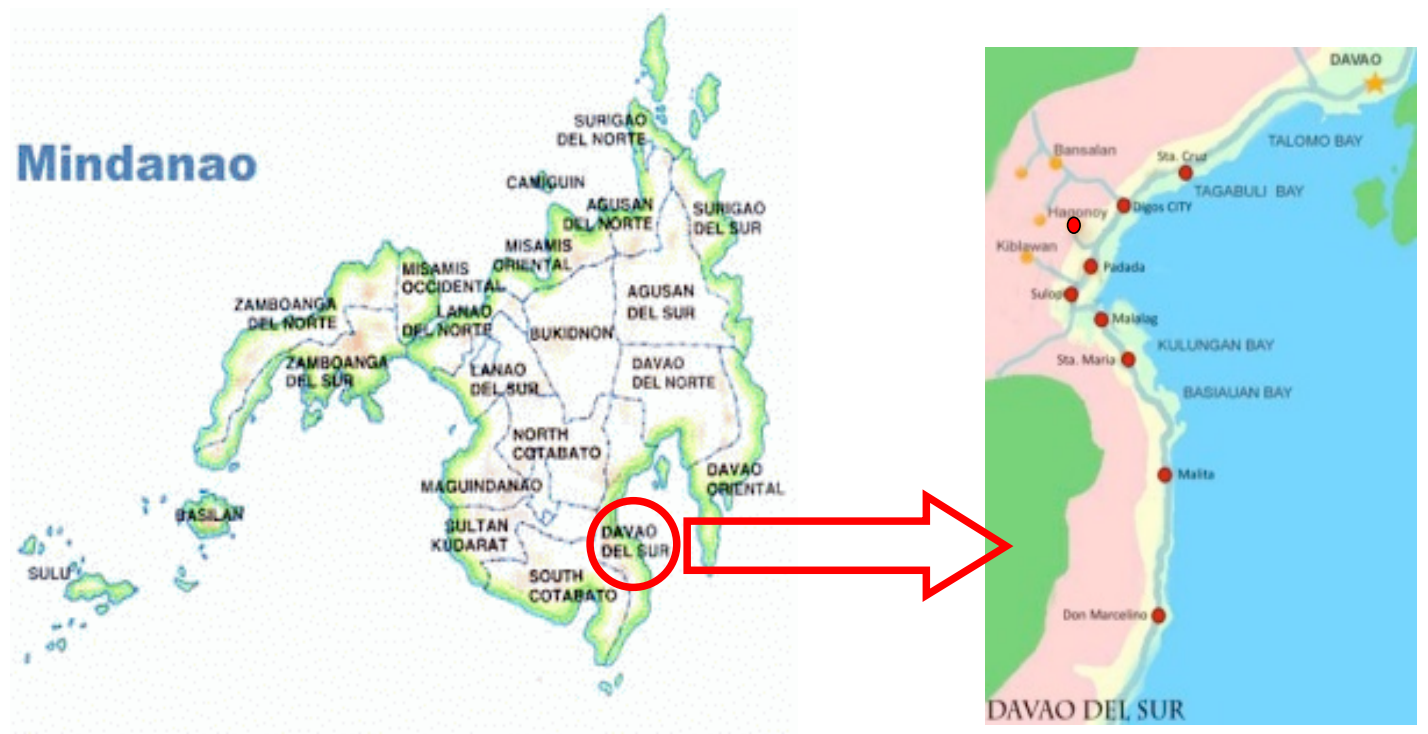

Fig. 1. The map of Davao del Sur where Philippine National Aquasilviculture Program (PNAP)

- Mangrove Rehabilitation Project are situated. 


\section{Research Design and Instrument}

Data in terms of growth and survival of mangroves were gathered through actual sampling, while the best practices and socio-demographic profile were gathered using questionnaires. The questionnaires were presented in Visayan dialect to facilitate understanding of question. It was administered through a personal interview.

\section{Respondents}

Respondents of the study were the PNAP mangrove rehabilitation project beneficiaries. They were randomly selected from the members of the organized beneficiaries of the nine (9) barangays. The beneficiaries are composed of fisherfolks. Thirty percent (30\%) from each identified people's organization's members were considered as respondents. Active members were given priority.

\section{Data Gathering}

\section{Growth}

Growth of mangroves planted in the different study sites was determined by back calculations. Initial data on growth was based on secondary data. Final growth rate was taken by actual measurement of the planted mangroves in selected sites. Comparison on growth increment of mangroves in different study sites was based on growth increment per day.

Growth Increment $=\frac{G t-G o}{T}$

Where: $G_{t}=$ is the final height of mangroves; $G_{0}=$ is the initial height of mangroves; and $\mathrm{T}=$ total number of days cultured

\section{Field Sampling Design}

To get the growth rate of planted mangroves, sampling stations were established in different sampling sites. A $10 \mathrm{~m} \times 10 \mathrm{~m}$ dimension plot was established in each sampling stations of every sampling sites. Each sampling plot serves as replicate. Spacing distance for each plot was 5 meters.
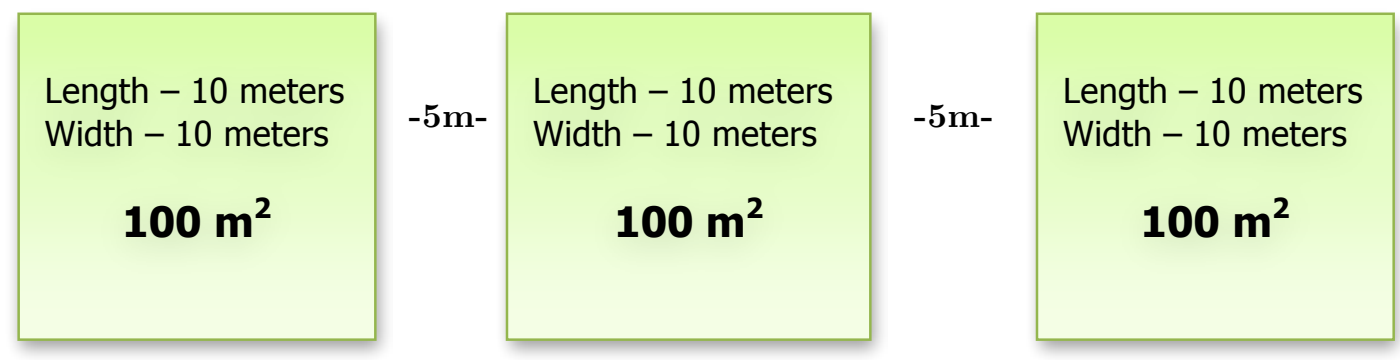

Fig. 2. The Experimental design for mangrove growth assessment and soil identification in the different project sites. 


\section{Survival Rate}

The survival rate in the different areas was taken by counting the entire number of mangroves survived over the number of mangroves planted in a particular barangay. This was computed by counting the total number of planted mangroves survived at present over the total number of planted mangroves. This was aided using the formula by Primavera et al., (2004).

$\%$ Survival $=\frac{\text { No.of Mangroves at time }(t)}{\text { Total No.of Mangroves Planted }} \times 100$

Preparation of Materials Needed

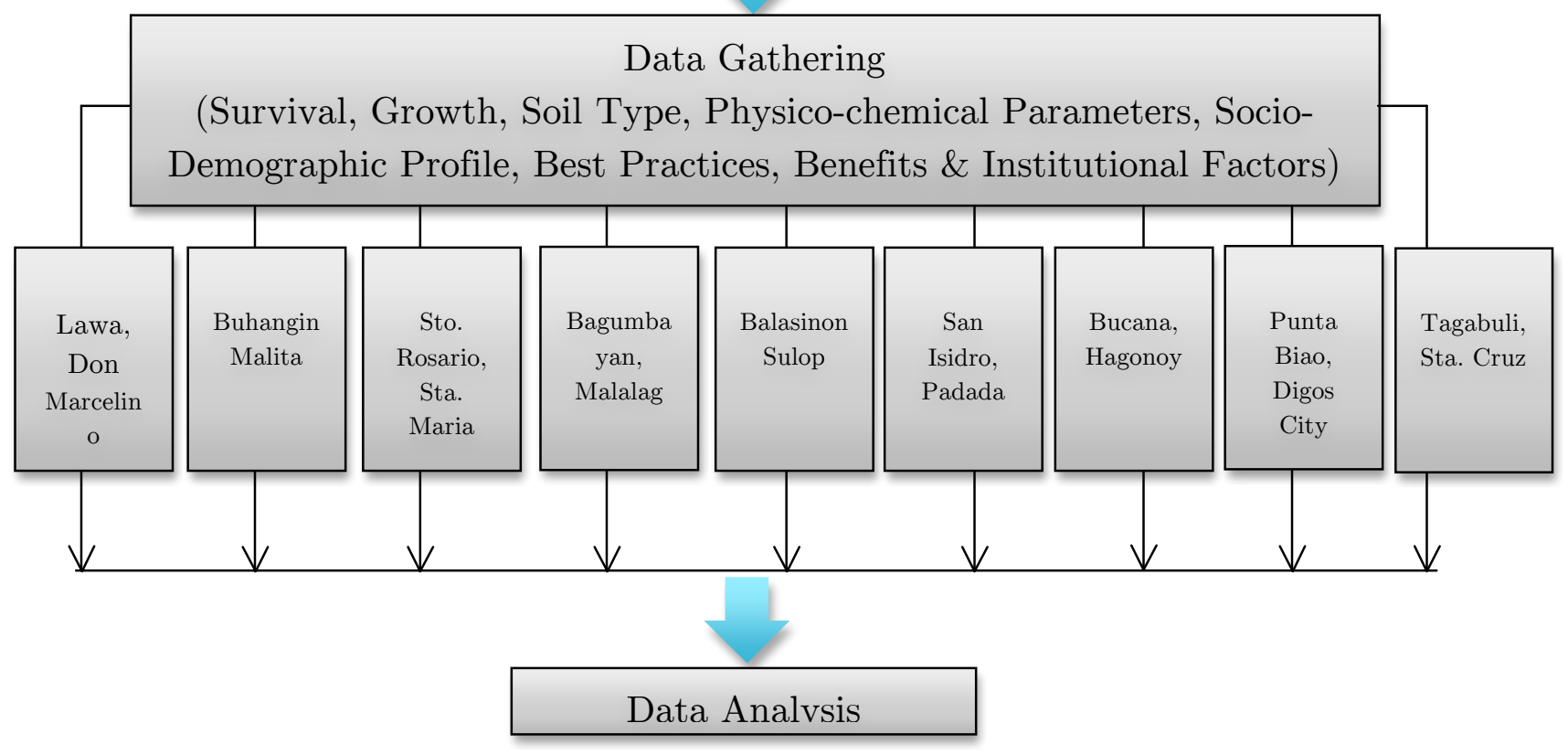

Fig. 4. Flow chart of the study

\section{Area Orientation}

Area orientation of the different study site was determined. These were into: tidal/mud flats and midland. Tidal/mud flats are shoreline area which was directly exposed to changing tidal levels and wave actions; whereas midland areas are areas exposed only during high tides and protected by heavy to moderate and sometimes no vegetation. 


\section{Soil Type Analysis}

The substrates type of the different study sites were analysed using touch/feel method. Soil sample was collected from five (5) sampling points from each study site. This was collected in a depth of twenty (20) centimeters.

\section{Statistical Analysis}

Analysis of Variance (ANOVA) was used in analysing data for growth using the Statistical Package for the Social Sciences (SPSS). The results that were having significant differences were analysed further using Tukeys Test.

\section{Percentage}

This was used to determine the relative share of respondents to specific questions.

$$
\%=f_{n \times 100}
$$

$$
\begin{aligned}
& \text { Where: } \%=\text { percentage } \\
& \qquad \begin{array}{l}
\mathrm{F}=\text { frequency } \\
\mathrm{N}=\text { total no. of samples }
\end{array}
\end{aligned}
$$

\section{Mean}

This was used to determine the average scores of the respondents.

$$
\mathrm{M}=\frac{\Sigma x}{N}
$$

Where: $\mathrm{M}=$ mean

$\Sigma=$ summation of scores

$\mathrm{N}=$ total no. of scores

\section{Results and discussion}

The results on the evaluation of the Success Indicators of the Mangrove Rehabilitation Project under Philippine National Aquasilviculture Program (PNAP) in Davao del Sur are presented in this chapter.

Nine (9) Barangays were considered as study sites to provide representation of the different areas. A total of 183,000 mangrove were planted under mangrove rehabilitation project of the PNAP, but only 147,757 propagules planted in nine (9) coastal barangays of Davao del Sur were included in this study. 


\section{Growth}

Result revealed that Punta Biao, Digos City and Bucana, Hagonoy were significantly higher $(\mathrm{p}>0.05)$ than the rest of the study sites with a growth increment of $0.0032 \mathrm{~cm} /$ day and $0.0031 \mathrm{~cm} /$ day respectively (Fig. 3). Statistically, the growth rate of the seven (7) areas (Lawa, Buhangin, Sto. Rosario, Bagumbayan, Balasinon, San Isidro and Tagabuli) were not significantly different to each other $(\mathrm{P}>0.05)$ with Sto. Rosario, Sta. Maria having the lowest growth rate of $0.0007 \mathrm{~cm} /$ day. Based on the different indicators evaluated (area orientation, species planted, soil type and salinity), Punta Biao and Bucana were found to be favorable to these criteria. The two (2) study sites where situated in midland areas, Rhizophorawas the species planted and with clay loam type of soil. No bearing on best practices as it showed the same strategies and techniques exerted by the beneficiaries with regards to monitoring, maintenance and general supervision of their respective sites (Table 6).

According to Katherisan and Moorthy 1993, shaded mangrove plants showed better growth performance compared to those plants directly exposed to sunlight. Punta Biao and Bucana mangrove plantation has an existing mangrove forest that serves as canopy of newly planted mangroves from sunlight. Intense light can damaged the mangrove and drop the photosynthetic rate (Cheesemanet al. 1991), hence, growth is affected.

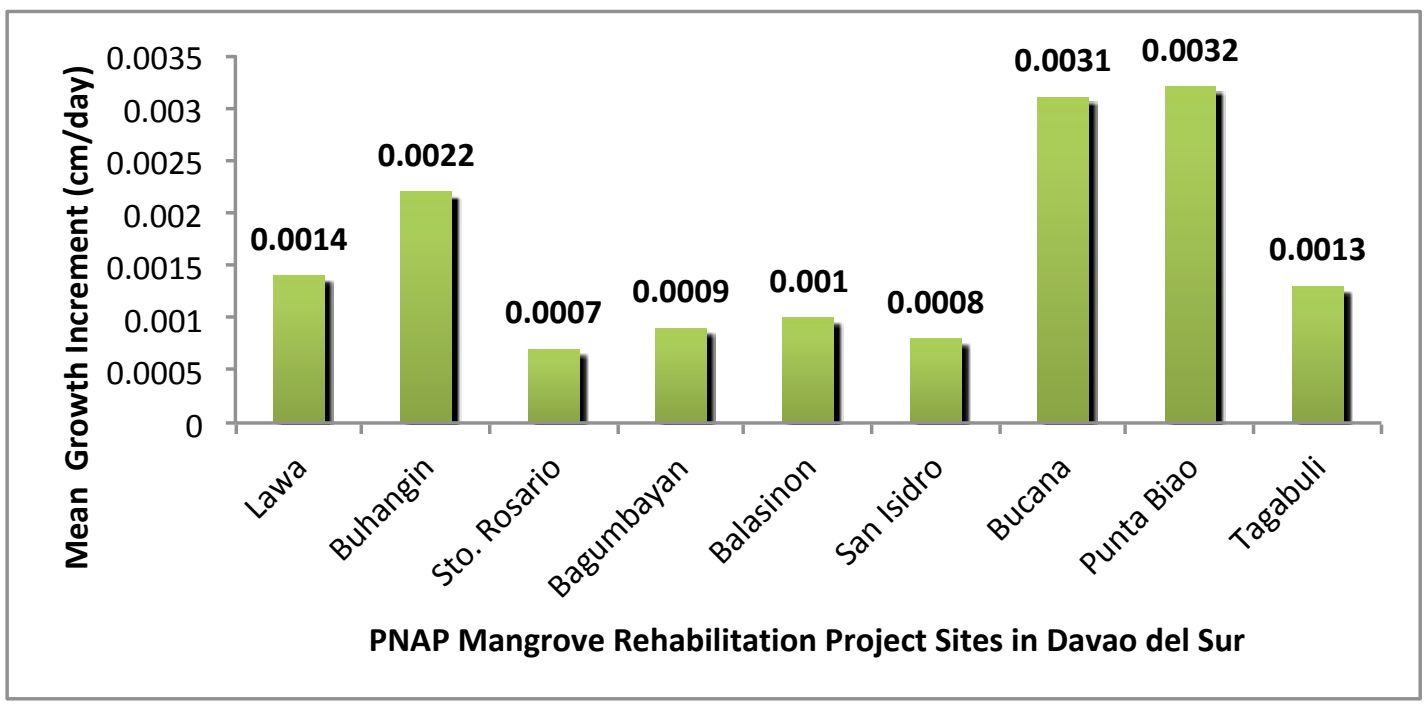

Fig. 3. Mean growth rate of mangroves planted under PNAP Mangrove Rehabilitation Project in Davao del Sur.

\section{Survival Rate of Mangroves}

Table 1 shows the survival rate of fully grown mangroves in the nine (9) study sites. The results showed an average survival of $52.99 \%$ which equivalent to an existing of 78,300 fully grown mangroves out of 147,757 planted propagules.

Results also showed that the major contributing factors to the survival of mangroves are: location of the area, species planted and soil type with other 
factors having minimal effect. Bucana, Punta Biao and Lawa were the only study sites situated in midland. The first two (2) areas having the highest survival rate of $99.87 \%$ and $99.62 \%$ and Lawa with $68.95 \%$. The area orientation of Punta Biao is in midland zone, hence, this is not directly exposed to waves and surges (Table $3)$.

The lowest survival was recorded in Balasinon, Sulop with 13.71\%. This area is located in a seaward zone where plants are exposed directly to winds and waves.

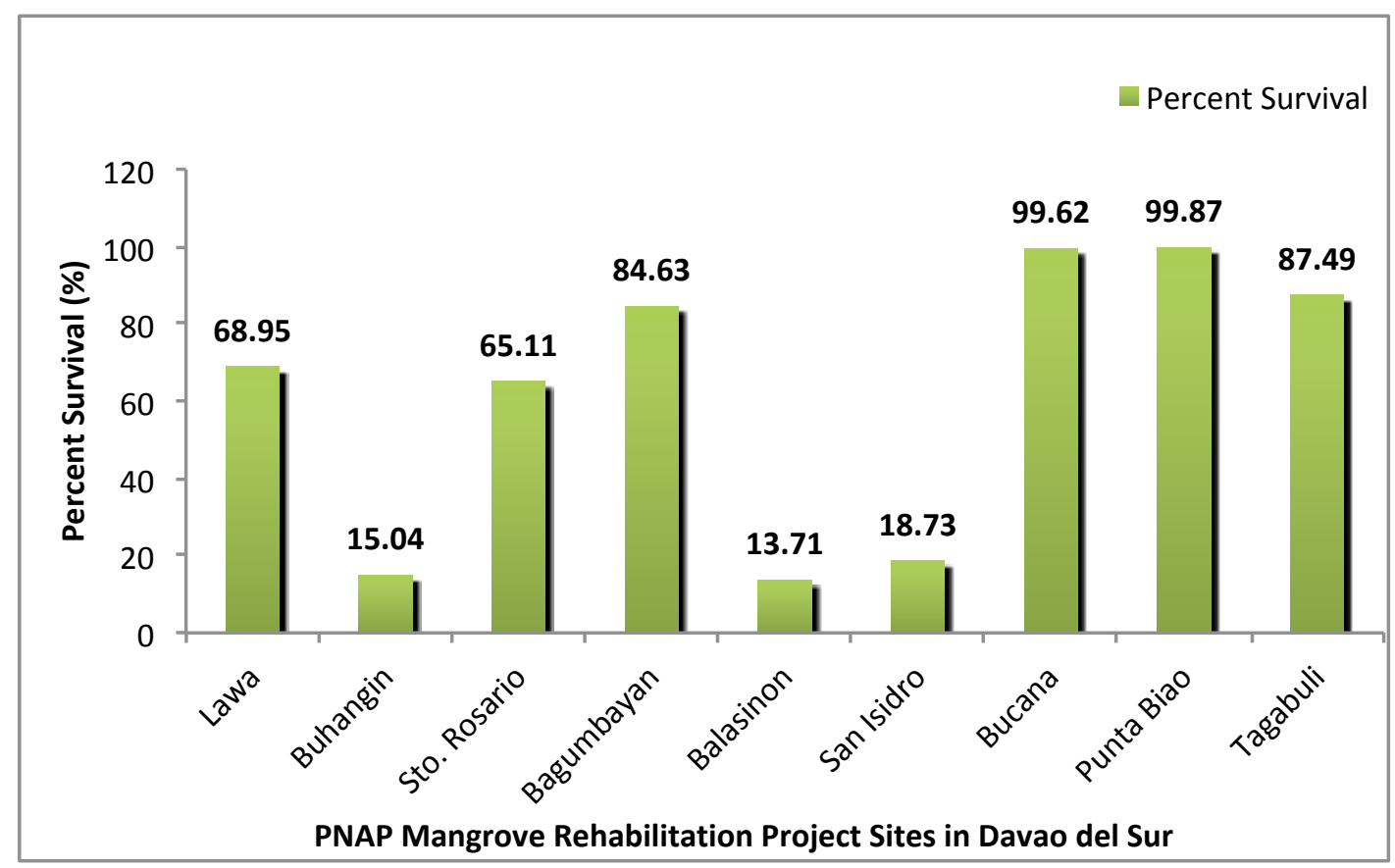

Fig. 4. The survival rate of mangroves of PNAP mangrove rehabilitation sites in Davao del Sur.

Choice of species of mangroves to be planted affects survival rate (Primavera and Esteban, 2008). These confirmed with the result of the study that Rhizophora species favoured clay loam soil type in the case of Punta Biao, Bucana, Lawa, Tagabuli and Sto. Rosario while Balasinon, Bagumbayan, San Isidro and Buhangin showed high mortality and recommended for other species suitable.

Best practices of the project beneficiaries showed that Punta Biao used mangroves that are matured and ripen and are ready for planting while in Balasinon, Sulop used propagated mangroves that is being nurtured in mangrove nursery for a long time (Table 6). One hundred percent (100\%) of Punta Biao PO-members attested that after collecting propagules, they did direct planting. These was evidently attested why Balasinon and other seaward areas have low survival rate since bagged mangroves after planted to a specified area took time to adapt its new environment. Nonetheless, given the loss substrate of excavation and erosion caused by wave actions were possible. Direct planting may be recommended in this case. 
Table 1. Summary of survival rates of mangroves planted under PNAP in selected sites in Davao del Sur.

\begin{tabular}{|c|c|c|c|c|c|}
\hline PROJECT SITES & $\begin{array}{l}\text { TOTAL } \\
\text { PLANTED }\end{array}$ & $\begin{array}{l}\text { PNAP TOTAL } \\
\text { SURVIVAL } \\
\text { (As of October } \\
2014 \text { ) }\end{array}$ & $\begin{array}{l}\text { PERCENT } \\
\text { SURVIVAL } \\
(\%)\end{array}$ & $\begin{array}{l}\text { TOTAL } \\
\text { SURVIVAL } \\
\text { (As of } \\
\text { February 28, } \\
2015 \text { ) }\end{array}$ & $\begin{array}{l}\text { PERCENT } \\
\text { SURVIVAL } \\
(\%)\end{array}$ \\
\hline Lawa, Don Marcelino & 16,257 & 15,991 & $98.36 \%$ & 11,210 & $68.95 \%$ \\
\hline Buhangin, Malita & 21,000 & 3,271 & $15.58 \%$ & 3,159 & $15.04 \%$ \\
\hline Sto. Rosario, Sta. Maria & 18,000 & 13,004 & $72.24 \%$ & 11,719 & $65.11 \%$ \\
\hline Bagumbayan, Malalag & 9,000 & 7,881 & $87.57 \%$ & 7,617 & $84.63 \%$ \\
\hline Balasinon, Sulop & 32,000 & 14,184 & $44.33 \%$ & 4,387 & $13.71 \%$ \\
\hline San Isidro, Padada & 10,000 & 3,360 & $33.60 \%$ & 1,873 & $18.73 \%$ \\
\hline Bucana, Guihing, Hagonoy & 6,500 & 6,500 & $100 \%$ & 6,475 & $99.62 \%$ \\
\hline Punta Biao, Digos City & 10,000 & 10,000 & $100 \%$ & 9,987 & $99.87 \%$ \\
\hline Tagabuli, Sta. Cruz & 25,000 & 22,000 & $88 \%$ & 21,873 & $87.49 \%$ \\
\hline TOTAL & 147,757 & 96,191 & $65.10 \%$ & 78,300 & $52.99 \%$ \\
\hline
\end{tabular}


Another finding is during the maintenance of mangroves collected. Majority of the project beneficiaries in Balasinon said that they conducted sorting of mangrove propagules and $14.29 \%$ of the total respondents confirmed that sorting activity took time up to 3 days. However, Punta Biao PO-members responded that 1 day was their maximum allotted time for stocking.

Jimenez and Lugo (1985) also mentioned that calamity like flooding is one of the causes of high mortality of planted mangroves. This could be the reason for low survival rate in Balasinon, Sulop since the area experienced periodic flash flooding, given the area is near in a populated centers where domestic waste are evident clinging to the plants (Plate 1).

Majority of the project sites in Davao del Sur used Rhizophora species that are endemic in their respective rehabilitation areas. Unsuitable choice of mangrove species by planting only Rhizophora sp. in all locations without regard to the specific-site natural mangrove zonation, is the factor most frequently reported causes of failure of mangrove rehabilitation projects in many Asia countries (Salmoet al., 2007). In species selection for mangrove rehabilitation, as much as possible, mangrove restoration should involve mixed species planting, or at least species other thanRhizophorashould be included (Macintosh and Ashton, 2002), those that are present in the area forming a stand or community.

Table 2. The mangrove species planted in the different project sites of PNAP in Davao del Sur

\begin{tabular}{cll}
\hline \hline PROJECT SITE & \multicolumn{2}{c}{ SPECIES } \\
\hline Lawa, Don Marcelino & Rhizophora sp. & \\
Buhangin, Malita & Rhizophora sp. & \\
Sto. Rosario, Sta. Maria & Rhizophora sp. & \\
Bagumbayan, Malalag & Rhizophora sp. & Avicennia sp. \\
Balasinon, Sulop & Rhizophora sp. & Avicennia sp. \\
San Isidro, Padada & Rhizophora sp. & \\
Bucana, Hagonoy & Rhizophora sp. & \\
Punta Biao, Digos City & Rhizophora sp. & \\
Tagabuli, Sta. Cruz & Rhizophora sp. & \\
\hline \hline
\end{tabular}

Table 2 shows the mangrove species in different PNAP mangrove rehabilitation project sites in Davao del Sur. Bagumbayan, Malalag and Balasinon, Sulop, project beneficiaries plantedmixed species of Rhizophoraspecies, Avicennia marina and a few of Sonneratia alba. It is very evident that Bagumbayan, Malalag showed excellent number of mangroves survived with $84.63 \%$ using two (2) mangrove species. This is also revealed that sandy clay soil type favoured for Avicennia and Sonneratia species.

Other factors include the infestation of pest, barnacles and oysters, astray animals, the physico-chemical parameters that include water salinity, $\mathrm{pH}$ and the direct exposure to sunlight in the area, and the anthropogenic activities done by the local settlers (using of fishing gears, boat traffic and gleaning) have negative impacts on mangrove plantations.

Project sites close to populated areas have problem of garbage and debris (fishing nets, plastic bags etc.), and domestic animals (e.g., pigs, goat etc.). This 
problem could probably contribute to the higher mortality rates of mangroves in the area.

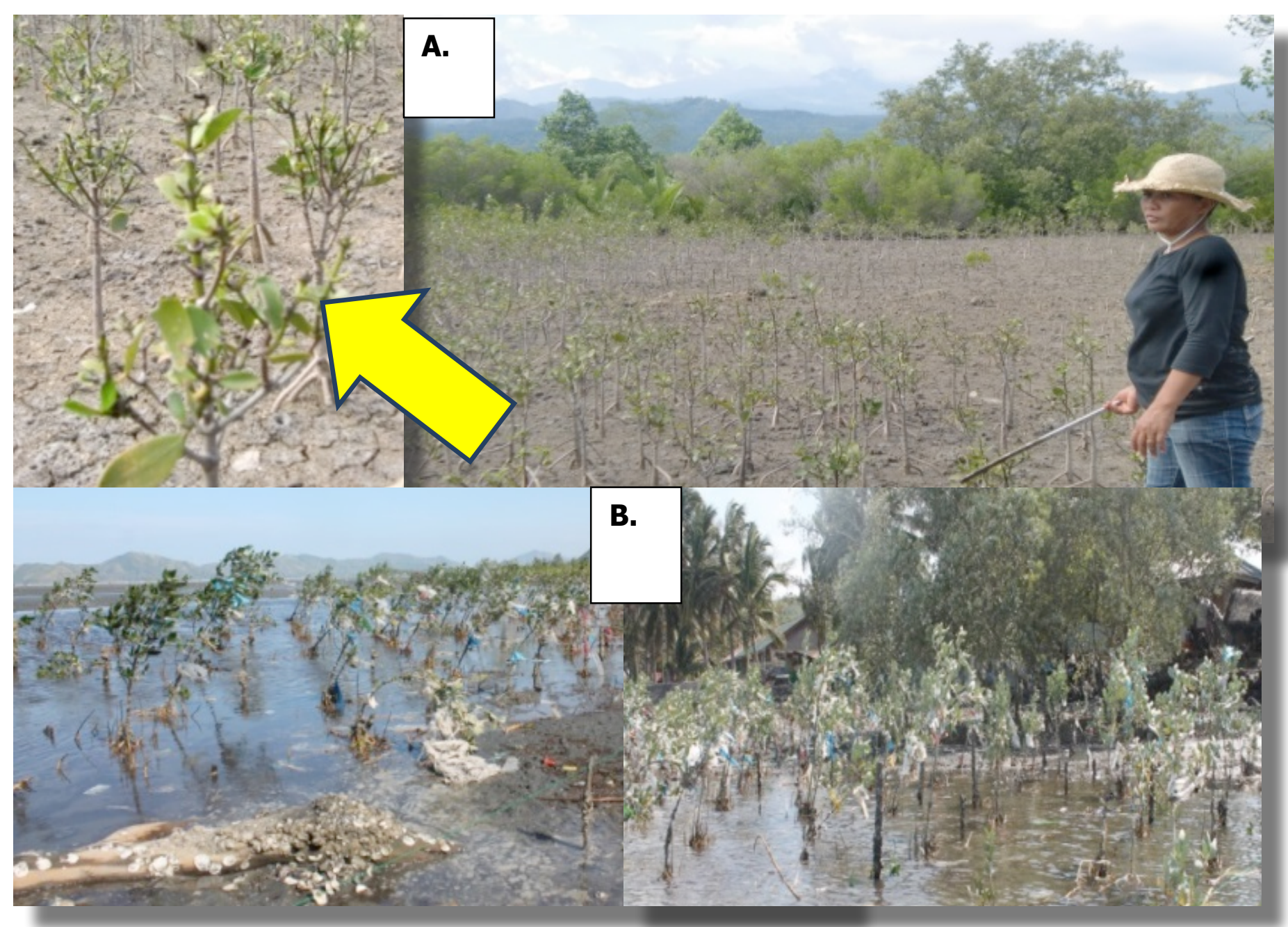

Plate 1. Damaged mangrove plantations due to (a) grazing of astray animals in Punta Biao, Digos City, and (b) garbage and debris in Balasinon, Sulop, Davao del Sur

\section{Area Orientation and Soil Type}

Table 3 shows the different substrate types and area orientation of the nine project sites under PNAP in Davao del Sur. These areas illustrated different soil texture based on the Feel Method technique as modified from Thein 1979. 
Table 3. Area orientation and soil type of the different project sites of PNAP in Davao del Sur.

\begin{tabular}{ccc}
\hline \hline PROJECT SITES & AREA ORIENTATION & SOIL TYPE \\
\hline Lawa, Don Marcelino & Midland Area & Clay Loam \\
Buhangin, Malita & Tidal/Mud Flat & Sandy Clay \\
Sto. Rosario, Sta. Maria & Tidal/Mud Flat & Clay Loam \\
Bagumbayan, Malalag & Tidal/Mud Flat & Sandy Clay \\
Balasinon, Sulop & Tidal/Mud Flat & Sandy Clay \\
San Isidro, Padada & Tidal/Mud Flat & Sandy Clay \\
Bucana, Hagonoy & Midland Area & Clay Loam \\
Punta Biao, Digos City & Midland Area & Clay Loam \\
Tagabuli, Sta. Cruz & Tidal/Mud Flat & Clay Loam \\
\hline \hline
\end{tabular}

Buhangin, Sto. Rosario, Bagumbayan, Balasinon, San Isidro and Tagabuli areas were located in tidal/mud flats which were directly exposed to tidal occurrences and wave actions. These are the areas that with less to no vegetation within them. While Lawa, Bucana and Punta Biao areas were a midland which were exposed only to tidal occurrences during high tides and were protected by moderate vegetation present along coastline. These areas have existing mangrove trees present who mutually serve as canopy or protection for the other mangroves (saplings) to a direct exposure to sunlight.

\section{Physico-chemical Parameters}

The prevailing physico-chemical parameters observed in the different sites is presented in Table 4. The observed pH ranged from 6.46 to 7.23 and the salinity ranged from 23ppt to 35ppt.

Table 4.The physico-chemical parameters in every project site.

\begin{tabular}{ccc}
\hline \hline PROJECT SITES & SALINITY & pH \\
\hline Lawa, Don Marcelino & $27 \mathrm{ppt}$ & 6.46 \\
Buhangin, Malita & $34 \mathrm{ppt}$ & 6.48 \\
Sto. Rosario, Sta. Maria & $34 \mathrm{ppt}$ & 7.23 \\
Bagumbayan, Malalag & $35 \mathrm{ppt}$ & 6.78 \\
Balasinon, Sulop & $34 \mathrm{ppt}$ & 6.75 \\
San Isidro, Padada & $29 \mathrm{ppt}$ & 7.04 \\
Bucana, Hagonoy & $23 \mathrm{ppt}$ & 6.81 \\
Punta Biao, Digos City & $25 \mathrm{ppt}$ & 6.93 \\
Tagabuli, Sta. Cruz & $26 \mathrm{ppt}$ & 7.14 \\
\hline \hline
\end{tabular}

The salinity in midland locations in the case of Bucana, Punta Biao and Lawa ranged from 23 to $27 \mathrm{ppt}$. These areas were planted with Rhizophora species of mangroves. The first two (2) areas where found to have the highest survival and growth rate among the nine (9) identified PNAP project sites in Davao del Sur. Hence, among the 9 project sites where the implementation of the project could be considered successful. 
These results only confirmed the findings of Primavera and Esteban 2008, Sindh coastal community development project report 2012 that inappropriate mangrove species and sites greatly affect the survival of mangroves.

\section{Socio-Demographic Profile of the Project Beneficiaries}

The socio-demographic profile of the project beneficiaries of the nine planted locations of the mangrove rehabilitation project is presented in the succeeding paragraph. Project beneficiaries' participation in mangrove planting activities varies from site preparations to monitoring, maintenance and general supervision. Findings revealed that women have medium participation in the preparation of planting materials. However, equal participation during the actual mangrove planting activity.

\section{Religion}

Majority of the residents in the different project sites are Roman Catholic (86.44\%). Out of the nine people's organizations, Lawa in Don Marcelino, Bagumbayan in Malalag, Balasinon in Sulop and Tagabuli in Sta. Cruz areRoman Catholic. Other denominations follow, such as a member of an Iglesiani Cristo (5.08\%), Baptist $(3.39 \%)$ and Iglesia Filipina Independencia $(5.08 \%)$.

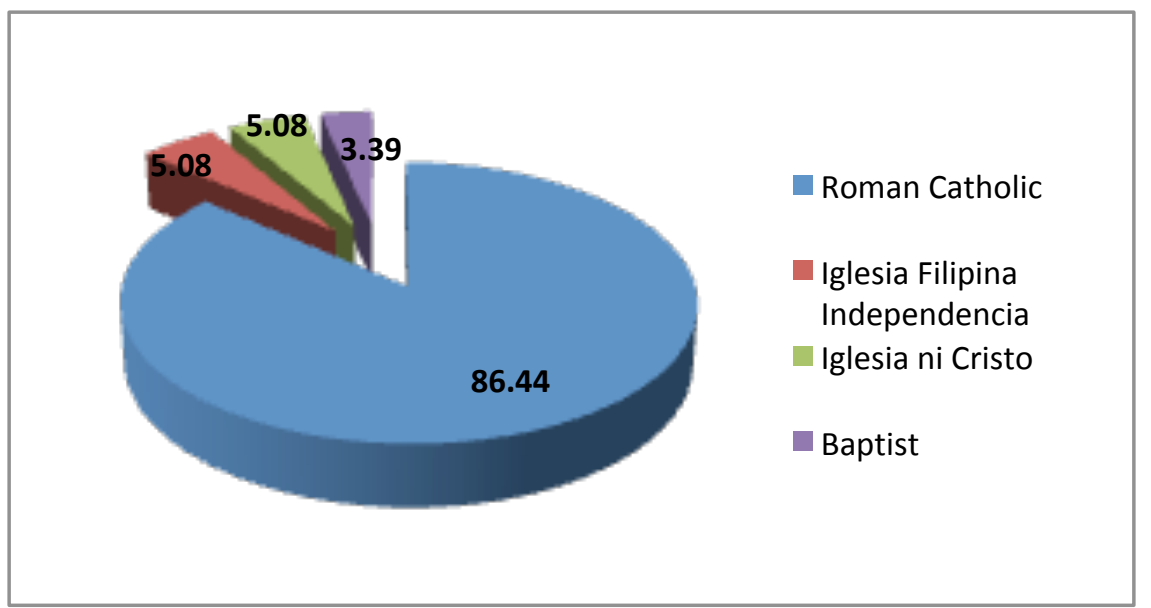

Fig. 5.The religion of PNAP project beneficiaries of the different project sites in Davao del Sur

\section{Civil Status}

As to the civil status, data shows dominance of the married memberbeneficiaries with $91.53 \%$ in the barangays of Buhangin, Sto. Rosario, Balasinon, San Isidro, Bucana, Punta Biao and Tagabuli. There were only $8.47 \%$ who are single member-beneficiaries. 


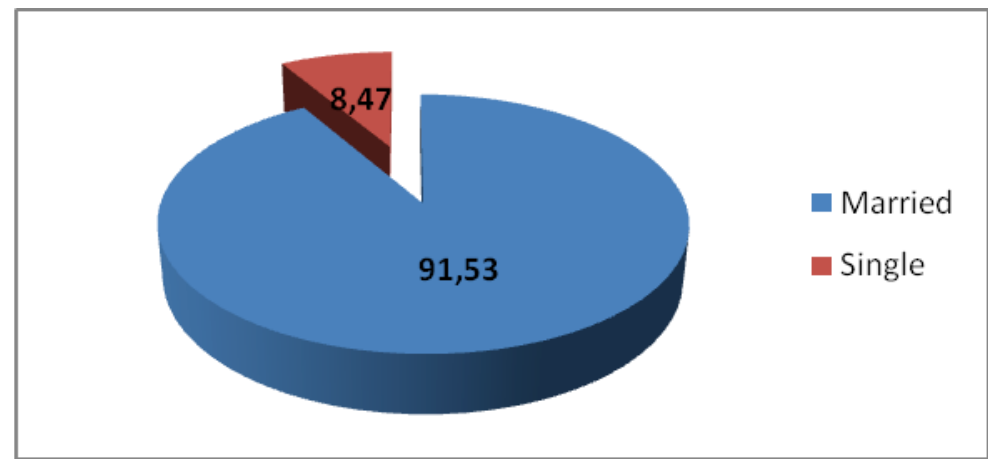

Fig. 6. The civil status of PNAP project beneficiaries of the different project sites in Davao del Sur

\section{Occupation}

Fishing is their major mean source of income with $49.15 \%$. Other means were as follows fish vending, gleaning, fish warden, fish cage and fishpond caretakers.

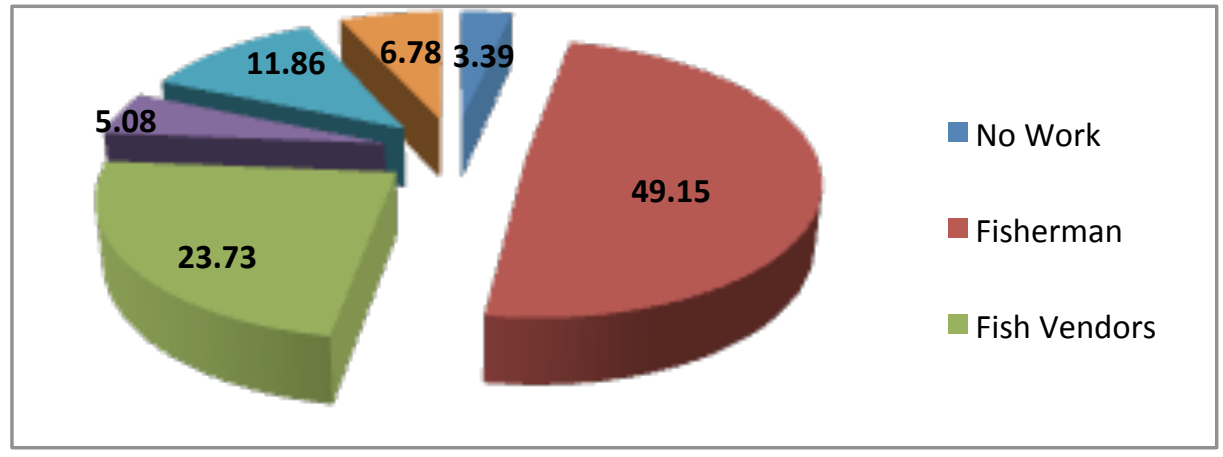

Fig. 7.Themajor occupations of PNAP project beneficiaries of the different project sites in Davao del Sur

\section{Tribe}

Most of the project beneficiaries were Cebuano with $83.05 \%$, Manobo $6.78 \%$, Kalagan $6.78 \%$ and Tagakaulo $3.39 \%$ tribes.

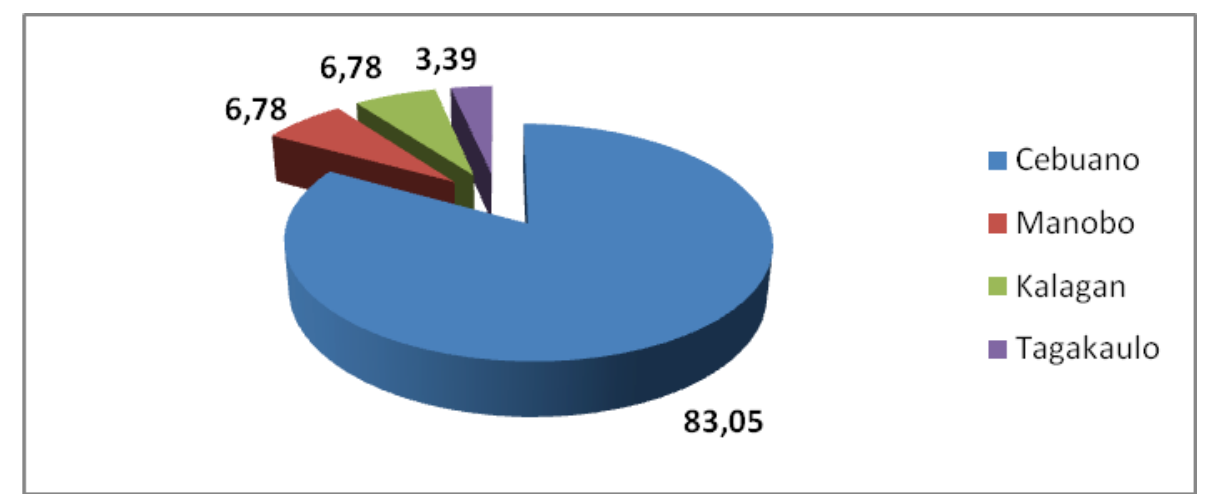


Fig. 8.The major tribes of PNAP project beneficiaries of the different project sites in Davao del Sur

\section{Educational Attainment}

Majority of the PNAP project beneficiaries are high school graduates with $54.24 \%$, followed by elementary level with $28.81 \%$ and few of them finished college with $16.95 \%$.

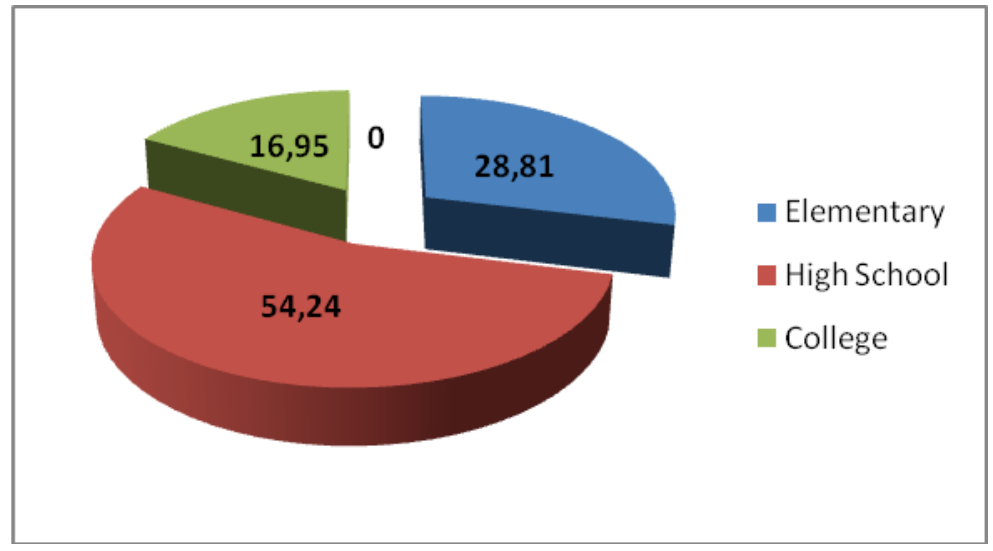

Fig. 9. The educational attainment of PNAP project beneficiaries of the different project sites in Davao del Sur

\section{Economic Benefits}

Majority $(100 \%)$ of the project beneficiaries are engaged in fishing as the main source of income. One hundred percent (100\%) said that all of them earned additional income ranging from Php 1,000.00 to Php 5,000.00 for every payout. Majority of them $(84.75 \%)$ used their additional income in buying basic needs such as rice and viand for their daily sustenance. Others $(8.47 \%)$ used it in paying tuition fees of their children and $6.78 \%$ used in paying their debt.

\section{Environmental Benefits}

Table 5 shows the environmental benefits of the project. All of the respondents agreed that the planted mangroves contributed to the increase in the fish catch in the area.

About $79.66 \%$ of the project beneficiaries interviewed conformed that mangroves provided protection to the coastal areas. Also, $81.36 \%$ of the respondents considered the planted mangroves to improve tourism in that area. The project was strongly supported by their barangay local government units (BLGU) (93.22\%). 
Table 5. The mean data for environmental benefits of the project beneficiaries

\begin{tabular}{c||cccccc}
\hline \hline \multirow{2}{*}{ Total } & \multicolumn{2}{c}{ YES } & \multicolumn{2}{c}{ NO } & \multicolumn{2}{c}{ Possibly } \\
& $\begin{array}{c}\text { No. of } \\
\text { Responses }\end{array}$ & $\%$ & $\begin{array}{c}\text { No. of } \\
\text { Responses }\end{array}$ & $\%$ & $\begin{array}{c}\text { No. of } \\
\text { Responses }\end{array}$ & $\%$ \\
\hline \hline 1.Recruitment & 59 & 100 & 0 & 0 & 0 & 0 \\
2.Serves as protection & 47 & 79.66 & 12 & 20.34 & 0 & 0 \\
3.Tourist attraction & 48 & 81.36 & 8 & 13.56 & 0 & 0 \\
4.BLGU supported & 55 & 93.22 & 1 & 1.69 & 3 & 5.08 \\
\hline \hline
\end{tabular}

\section{Best Practices Employed by the Project Beneficiaries}

The result of the evaluation on best practices employed by the project beneficiaries is presented in Table 6. Majority of the project beneficiaries said that they picked and harvested mangrove propagules by climbing the mangrove trees with $83-100 \%$ out of 8 project sites, and $16.67 \%$ of 4 barangays said that they picked from mangrove forest. No effect in selecting mangrove propagules since $100 \%$ of the 8 project sites used matured propagules for planting, except for Balasinon, Sulop (100\%) that used bagged mangroves. With 83-100\% (9 project sites) said that after collecting mangrove propagules, they directly planted it in their respective rehabilitation sites. Although in some cases, if the mangroves will be stocked, $71-100 \%$ said that 1 day will be a best stocking interval. Through visual observation, project beneficiaries observed that exceeding 1 day will result to infestation of pest and insects as happened in Balasinon, Sulop, Davao del Sur.

A $100 \%$ favoured of bringing mangrove propagules in the project sites were aided using sack, plastic handlers and the like. Before mangrove planting activity, 40-100\% (8 project sites) of the project beneficiaries said that they did area preparations like making markings where to plant mangroves. Other activities employed were the establishment of stakes to support the planted mangroves as it grows and protected from being uprooted caused by tidal actions and other factors.

On the actual day of planting, 25-100\% of the total respondents recommended to make a hole before placing the mangroves on a specified area. It was aided using digging materials, shovel and others.

Regular monitoring is fundamental in determining whether objectives of reforestation have been achieved. In this case, a majority or $62.71 \%$ of the total respondents said that they monitor the planted mangroves in every other day. Few of them practiced scraping activity to the body of the mangrove propagules to minimize the infestation of barnacles and oysters, for instance. 
SCIENCE

Table 6. The responses of the PNAP project beneficiaries in terms of best practices employed

\begin{tabular}{|c|c|c|c|c|c|c|c|c|c|c|c|c|c|c|c|c|c|c|}
\hline $\begin{array}{l}\text { Sampling } \\
\text { Stations }\end{array}$ & $\begin{array}{l}\text { No. } \\
\text { of } \\
\text { Resp } \\
\text { onses } \\
\end{array}$ & $\%$ & \multicolumn{2}{|c|}{$\begin{array}{l}\text { BUHANG } \\
\text { IN } \\
\text { No. } \\
\text { of }\end{array}$} & \multicolumn{2}{|c|}{$\begin{array}{l}\text { STO. } \\
\text { ROSARIO } \\
\text { No. } \\
\text { of }\end{array}$} & \multicolumn{2}{|c|}{$\begin{array}{l}\text { BAGUMB } \\
\text { AYAN } \\
\text { No. } \\
\text { of }\end{array}$} & \multicolumn{2}{|c|}{$\begin{array}{l}\text { BALASIN } \\
\text { ON } \\
\text { No. } \\
\text { of }\end{array}$} & \multicolumn{2}{|c|}{$\begin{array}{l}\text { SAN } \\
\text { ISIDRO } \\
\text { No. } \\
\text { of }\end{array}$} & \multicolumn{2}{|c|}{$\begin{array}{l}\text { BUCANA } \\
\text { No. } \\
\text { of }\end{array}$} & \multicolumn{2}{|c|}{$\begin{array}{l}\text { PUNTA } \\
\text { BIAO } \\
\text { No. } \\
\text { of }\end{array}$} & $\begin{array}{l}\text { TAG } \\
\text { I } \\
\text { No. } \\
\text { of } \\
\text { Res } \\
\text { pons } \\
\text { es }\end{array}$ & BUL \\
\hline \multicolumn{19}{|c|}{ 1.Collection of Mangrove Propagules } \\
\hline A. From Trees & 12 & 100 & 6 & 100 & 4 & 66.67 & 1 & 20 & 7 & 100 & 5 & 83.33 & 5 & 83.33 & 5 & 83.33 & 5 & 83.33 \\
\hline B. From Shoreline & - & - & - & - & 1 & 16.67 & 1 & 20 & - & - & - & - & - & - & - & - & - & - \\
\hline C. From Forest & - & - & - & - & 1 & 16.67 & 3 & 60 & - & - & 1 & 16.67 & 1 & 16.67 & 1 & 16.67 & - & - \\
\hline \multicolumn{19}{|c|}{ 2.Selection of Mangrove Propagules } \\
\hline A. Matured & 12 & 100 & 6 & 100 & 6 & 100 & 5 & 100 & - & - & 6 & 100 & 6 & 100 & 6 & 100 & 5 & 100 \\
\hline $\begin{array}{l}\text { B. w/ Roots } \\
\text { C. Bagged }\end{array}$ & - & - & - & - & - & - & - & - & - & - & - & - & - & - & - & - & - & - \\
\hline Mangroves & - & - & - & - & - & - & - & - & 7 & 100 & - & - & - & - & - & - & - & - \\
\hline \multicolumn{18}{|c|}{ 3.Maintenance before Mangrove Planting } & \\
\hline $\begin{array}{l}\text { Planted } \\
\text { B. Direct Planting } \\
\text { E. Sort before }\end{array}$ & $\begin{array}{l}1 \\
1\end{array}$ & $\begin{array}{l}8.33 \\
8.33\end{array}$ & - & $\begin{array}{l}- \\
100\end{array}$ & - & $\begin{array}{l}- \\
100\end{array}$ & $\begin{array}{l}- \\
4\end{array}$ & $\begin{array}{l}- \\
80\end{array}$ & - & - & $\begin{array}{l}6 \\
-\end{array}$ & $\begin{array}{l}100 \\
-\end{array}$ & - & - & - & $\begin{array}{l}- \\
100\end{array}$ & $\begin{array}{l}- \\
5\end{array}$ & $\begin{array}{l}- \\
100\end{array}$ \\
\hline $\begin{array}{l}\text { Planting } \\
\text { 4.Stocking Period }\end{array}$ & $\begin{array}{l}10 \\
\text { (in days }\end{array}$ & $\begin{array}{l}83.33 \\
\text { befor }\end{array}$ & \multicolumn{15}{|c|}{ 4.Stocking Period (in days) before it was Planted } & - \\
\hline A. 1 Day & 10 & 83.33 & 6 & 100 & 6 & 100 & 5 & 100 & 5 & 71.43 & 6 & 100 & 4 & 66.67 & 6 & 100 & 5 & 100 \\
\hline B. 2 Days & 2 & 16.67 & - & - & - & - & - & - & 1 & 14.29 & - & - & 1 & 16.67 & - & - & - & - \\
\hline C. 3 Days & - & - & - & - & - & - & - & - & 1 & 14.29 & - & - & 1 & 16.67 & - & - & - & - \\
\hline \multicolumn{19}{|c|}{ 5.Means of transporting Mangrove Propagules } \\
\hline A. Packed & 12 & 100 & 6 & 100 & 6 & 100 & 5 & 100 & 7 & 100 & 6 & 100 & 6 & 100 & 6 & 100 & 5 & 100 \\
\hline
\end{tabular}




\section{Open Science Journal}

Research Article

\section{Preparations prior to Mangrove Planting}
A.Markings
B. Used of Lines

$83.33 \quad 3 \quad 50$

$8.33 \quad 3 \quad 50$

C.Landmarks

7.Mangrove Planting Strategies and Techniques

A. Direct sticking

B. Used of Digging

Materials

C. Hole Making

D. Grown

Propagules

E. Tying

8 .1. Maintenance in terms of guarding and monitoring

A.Everyday

B. Every other Day 1

C. Once a Week

D. Twice a Week

8.2. Maintenance in terms of Cleaning and General

Supervision

A. Everyday

Cleaning

B. Scraping

Regularly

C. Tying

$\begin{array}{lllll}- & 3 & 50 & 3 & 50\end{array}$

D. Fencing

$\begin{array}{lllll}- & - & - & - & - \\ 100 & 6 & 100 & 4 & 66.67 \\ & & & & \end{array}$

33.33 


\section{Institutional Factors}

Keys informants of the project were also given a questionnaire to give some feedbacks about the overall attainment of the project. Key informants include the Community Organizers (COs), Project and Study Leaders, DA-BFAR Technical Staff, Project Monitoring Office (PMO) among others. One Hundred Percent $(100 \%)$ attested that there is an executed memorandum of agreements (MOA) of the Bureau of Fisheries \& Aquatic Resources (BFAR) and the Southern Philippines Agri-business and Marine and Aquatic School of Technology (SPAMAST) in implementing the Philippine National Aquasilviculture Program (PNAP). To ensure effective implementation, project team members was given training like hands-on training on resource rehabilitation and aquasilviculture, leadership training and capability building workshop and the like.

Regional Steering Committee (RSC) was created and existed to supervised policy implementation and oversee the Project Monitoring Office (PMO). RSC scheduled to meet yearly for 1-3 times or more as the need arises. In Davao del Sur, the Project Monitoring Office (PMO) existed to oversee the operations and implementation of the program in the province. Three (3) Community Organizers were hired to facilitate and implement PNAP in the grassroot levels. Community Organizers were rated excellent or 1.83 in project presentation to Local Government Units (LGUs), Barangay Local Government Units (BLGUs) and People's Organizations (POs). They organized and strengthened people's organizations who served as project beneficiaries and front liners during the whole project duration. They were tasked also to conduct trainings and dissemination of information, and supervised mangrove planting, maintenance and general supervision of the different project sites. A mean satisfactory rating of 2 for the promotion of environmental awareness, value formations, team building, gender awareness and related technical aspects in the project implementation. As well as in ensuring appropriate, accurate and timely payment of financial obligations to the project beneficiaries, community organizers got mean satisfactory rating of 2.17 .

There is a need of an integrated strategy for rehabilitation of degraded ecosystems together with conservation such that rehabilitation that improves livelihoods of local communities (Tabuchi, 2003). Evidence in this study for institutional factors indicated that community organizers hired got a satisfactory rating of 2.17 which might be implies that something should be addressed on the management strategies, as such, the timely payment of financial obligations to the project beneficiaries does not regularly achieved on a specified day and time due to government protocols of processing cash and related expenses. This was confirmed with $33.33 \%$ of the PO-members in Sto. Rosario, Sta. Maria that the guarding and general supervision of the rehabilitated sites was conducted once a week.

The Department of Environment and Natural Resources (DENR) Community Environment and Natural Resources (CENRO) also extended their technical assistance. DENR-CENRO serves as technical consultant, like in the case of San Isidro, Padada and Balasinon, Sulop on which PNAP Mangrove Rehabilitation Project are situated. The above-stated areas are in line with the 
DENR's Key Biodiversity Areas (KBA) and in thrust with the Integrated Coastal Zonation Mapping Plan (IZCMP) of their respective municipalities.

Majority of the PNAP Mangrove Rehabilitation Project sites were identified as Key Biodiversity Areas (KBAs). These are the areas identified reforestation/afforestation sites. Most of the project beneficiaries met the criteria as recipient's sets by the management and in validation of the Fisheries and Aquatic Resources Management Councils (FARMCs). They're willing to participate in the program implementation and abide by the terms and conditions therein. They're also bonafide resident fisherfolks in their respective barangays and identified and included in the list as marginal sector.

Key informants rated excellently as to PNAP objectives of ensuring resource sustainability, attaining food security and contribute in alleviating poverty incidence.

\section{Summary, conclusions and recommendation}

\section{Summary}

The study was conducted in the barangays of Lawa in Don Marcelino, Buhangin in Malita, Sto. Rosario in Sta. Maria, Bagumbayan in Malalag, Balasinon in Sulop, San Isidro in Padada, Bucana in Hagonoy, Punta Biao in Digos City, and in Tagabuli in Sta. Cruz, Davao del Sur from February 21 to 28, 2015 .

The study aimed to evaluate the success indicators of which was based on survival and growth of mangroves planted under mangrove rehabilitation project of the Philippine National Aquasilviculture Program (PNAP) in the nine planted areas mentioned. Actual measurement of height and survival of mangroves in the different project sites made through a one shot sampling.

Results revealed significant difference $(\mathrm{P}<.05)$ in terms in growth in length (cm/day) obtained among the nine planted areas. Punta Biao, Digos City has exhibited the highest increment of $0.0032367 \mathrm{~cm} /$ day and Sto. Rosario, Sta. Maria as lowest mean height of $0.0006667 \mathrm{~cm} /$ day. In terms of survival rate, the highest was observed in Punta Biao, Digos City with $99.87 \%$ and followed by Bucana, Guihing, Hagonoy with 99.62\%.The lowest was recorded in Balasinon, Sulop with $13.71 \%$.

There were two (2) type of area orientation found in the different project sites, midland and tidal/mud flats areas. Clay loam and sandy clay were identified as soil types. High survival and high growth increment was observed in midland area and with clay loam type of soil. Low survival in seaward area.pH reading will range from 6.46 and 7.23 while salinity will also range from $23 \mathrm{ppt}$ 35 ppt.

Some of the contributing factors that influenced higher survival rate of PNAP Mangrove Rehabilitation Project in Davao del Sur includes the used of matured mangrove propagules, staking prior to mangrove planting, regular monitoring at least every other day and carefully scraping epiphytes (e.g. barnacles and oysters) during mangrove's early stage. This practices observed in all project sites regardless of percentage rate recorded. 


\section{Conclusions}

Among the nine project sites, Bucana, Hagonoy and Punta Biao in Digos City showed higher survival rates of PNAP planted mangroves in the province. The lowest was recorded in San Isidro, Padada. These were attributed with soil type, area orientation, species selection, physico-chemical parameters.Survival rate and growth increment will be dependent on its area orientation, soil type and appropriate species.

The selection of appropriate species of mangroves in Davao del Sur should be considered. The presence of mangrove species thriving in the area could be a guide. This also reveals that the species of Rhizophora is favourable only in clay loam soil type (common in tidal/mudflat) and Avicennia for sandy clay soil (common in seaward areas).

Some best practices revealed staking, used of matured propagules, regular monitoring and scraping contributed to high survival rates.

\section{Recommendations}

The used of mixed mangrove species for mangrove rehabilitation project such as Avicceniaand Sonneratia species are recommended to use when conducting mangrove planting activity in seaward areas having high water salinity.

For an efficient direct planting activity, staking is highly recommended to support the plant against wave actions, epiphytes (e.g. barnacles and oysters) and protected from being uprooted caused by other factors.

\section{References:}

ALTAMIRANO, J.P., LEBATA, H.L., JUNEMIE, M.A. and SADABA, B.R. 1980.Land-building and stabilization by mangroves. Environmental Conservation 1 (4): 285-294.

BATAY-AN, A. S. and BYERS, T. 2006.Multi-Partnership Mangrove Rehabilitation of Dasol Bay Strategies and Results. Manila, Philippines.

CALUMPONG, H. P., and MENEZ, E., 1997.Field guide to common Mangrove and Sea Grass with algae of the Philippines.Bookmarks Inc. 264 A. Pablo Ocampo St. Avenue, Makati City, Philippines.Pp 83.

CASTAŇOs, M.T., GARCIA, L., PRIMAVERA, J.H., and SURTIDA, M.B. 2000.Mangrove Friendly Aquaculture.Aquaculture Department, Southeast Asian Fisheries Development Center, Tigbuan, Iloilo, Philippines.

CHEESEMAN, J.M CLOUGH B. F., CARTER D.R and ,LOVEDLOCK, O.J. 1991. The analysis of photosynthetic performance in leaves under field conditions: a case study using bruguiera Mangroves. Photosynthetic Rs. 29 (1): 11-22.

DIETA, R. and DIETA, F. 2014.The Philippine National Aquasilviculture Program. Paper presented during the SEAFDEC-AQD International Workshop on Resource Enhancement and Sustainable Aquaculture Practices 
in Southeast Asia held at Punta Villa Resort, Iloilo City, Philippines on March 5-7, 2014.

GEneralaO, I., FUEnTES, A., LlAmeG, M., ElEMinO, M., AVENIDO, P., LUBAT, G., PACYAO, J.P., and PATAGOC, R., 2014.Community Based Mangrove Resource Management and Aquasilviculture: A Coastal Conservation and Livelihood Project in Davao del Sur. Paper presented during the $4^{\text {th }}$ Biennal Convention of the Philippines Association of Extension Program Implementors, Inc. (PAEPI) at Mindanao University of Science and Technology (MUST), Claro M. Avenue, Cagayan de Oro City, Philippines on October $27-29,2014$.

GOVE, M.G. 1993.The Effect on the Salinity Change on Mangroves. Bangkok, Thailand. Morrissey.

GROSS, M.G. 1993.Oceanography: A review of the Earth. Charles E. Ment Publishing Company, A Bell and Howell Co., Columbus, Ohio. Pp 260-261.

JIMENEZ, J.A. and LUGO, A.E. 1985.Tree mortality in mangrove forests.Biotropica 17 (3): 177-185.

KATHERISAN, K. and MOORTHY, P. 1993. Influence of different irradiance on growth and photosynthetic characteristics in seedlings of Rhizophoraspecies. Photosyntheica 29(1): 143-146.

KATHERISAN, K. and RAMESH, M.X. 1991. Establishment of seedlings of mangrove. Indian for 17(3): 93-95.

MACINTOSH, D.J. and ASHTON, E.C. 2002.Mangrove Rehabilitation and intertidal Biodiversity: A study in the Ranong mangrove Ecosystem, Thailand. Estuarine, Coastal and Shelf Science, 55,331-345.

MELANA, D. 2000.Mangrove Management and Development in the Philippines. Paper presented during the meeting on Mangrove and Aquaculture Management held at Kasetsart University, Bangkok, Thailand on February 14 $-16,2000$.

MIDAS, J. 1995.Pre-investment Study for a Coastal Resource Management Program in Thailand, in Report Summit to the World Bank and the Ministry of Agriculture and Cooperation, RTG.

MORALDE, G. 2007.Gender Participation in Mangrove Rehabilitation Project among Barangays in Samal Island, Davao Province Region XI. Paper presented during the 10th National Convention on Statistics (NCS) EDSA Shangri-La Hotel, Manila, Philippines on October 1-2, 2007.

PRIMAVERA, J. and ESTEBAN, J. 2008.A Review of Mangrove Rehabilitation in the Philippines: Success, Failures and Future Prospects. Wetlands.Ecology.Management.

PRIMAVERA, J. H., SADABA, R.B., LEBAYA, J.H.L., and ALTAMIRANO, V.P., 2004.Handbook of Mangrove on the Philippines - Panay.Aquaculture Department, Southeast Asian Fisheries Development Center, Tigbuan, Iloilo, Philippines.Pp 1-10.

ONRIZAL, F.P, and MASHHOR, M. 2009.Natural Regeneration and Rehabilitation of Aceh Mangrove Forests Five Years after the 2004 Indian Ocean Tsunami. Paper presented at "An International Workshop for Conservation Genetics of Mangroves" at the Iriomote Station of the Tropical Biosphere Research Center, University of Ryukyus on February 11-12, 2009. 
SALMO, S.G., TORIO, D.T., and ESTEBAN, J.M.A. 2007.Evaluation of Rehabilitation Strategies and Management Schemes for improvement of Mangrove Management Programs in Lingayen Gulf. Science Diliman 19:24-34.

SAMSON, M. AND ROLLON, R. 2008. Growth Performance of Planted Mangroves in the Philippines: Revisiting forest management strategies. Royal Swedish Academy of Sciences, 37, 234-240. Philippines.

SANOY, Y.A. 2008.Species diversity of mangroves in New Argao, Malita, Southern Philippines.Undergraduate Thesis.Southern Philippines Agribusiness and Marine and Aquatic School of Technology (SPAMAST), Malita, Davao del Sur.

SMITH, T.M. 1998.Elements of Ecology. Prentice Hall, New York. Fourth Edition.Pp 504-505.

TAYOGTOG, J. 2014.Survival of Mangrove (Rhizophora sp.) Planted in the Mangrove Rehabilitation and Conservation Project in Sta. Maria and Malita, Davao del Sur. Undergraduate Thesis. Southern Philippines Agri-business and Marine and Aquatic School of Technology (SPAMAST), Malita, Davao del Sur.

THEIN, M.J. 1979.Field Guide to soil texture classification. Bookmarks Inc. 264 A. Pablo Ocampo St. Avenue, Makati City, Philippines.

WALSH, G. E. 1974.Mangroves In: Ecology of halophytes. Academic Press, New York.

WALTERS, BRANDLEY B. 1999. Local Mangrove Planting in the Philippines: Are Fisherfolk and Fishpond Owners Effective Restorationists?.Published in Restoration Ecology Volume 8(3):237-246.Department of Geography, Mount Allison University, 144 Main St., Sackville, N.B. Canada.

WALTON, M. E., VAY, L. L., LEBATA, J. H., BINAS, J., and PRIMAVERA, J. H. 2007.Assessment of the Effectiveness of Mangrove Rehabilitation using Exploited and Non-Exploited Indicator Species.Biological Conservation, 138, 180-188.Ilo-ilo, Philippines.

WEBSTER THIRD NEW INTERNATIONAL DICTIONARY.1980.Prentice Hall, New York.

YPARRAGUIRE, R. 2008. Characterization of Mangrove Areas And Profile of Human Activities in Selected Barangays of SANPASADA. Funded By Philippine Center For Population And Development, Inc., Davao City, Philippines.

http://www.asha.org/academic/DSPIndicatorsSuccessSP.html 


\section{Appendix I}

SUMMARY DATA AND ANALYSIS OF VARIANCE (ANOVA) OF THE GROWTH RATE (cm/day) OF MANGROVES PLANTED UNDER THE PHILIPPINE NATIONAL AQUASILVICULTURE PROGRAM (PNAP) MANGROVE REHABILITATION PROJECTS IN DAVAO DEL SUR, PHILIPPINES

\begin{tabular}{|c|c|c|c|c|c|}
\hline \multirow{2}{*}{ Project Sites } & \multicolumn{3}{|c|}{ REPLICATION } & \multirow{2}{*}{$\begin{array}{c}\text { TREATMENT } \\
\text { TOTAL }\end{array}$} & \multirow{2}{*}{$\begin{array}{c}\text { TREATMENT } \\
\text { MEAN }\end{array}$} \\
\hline & 1 & 2 & 3 & & \\
\hline Lawa, Don Marcelino & 0.0017 & 0.0013 & 0.0012 & 0.0042 & 0.0014 \\
\hline Buhangin, Malita & 0.00102 & 0.00121 & 0.0013 & 0.00353 & 0.001176667 \\
\hline Sto. Rosario, Sta. Maria & 0.0007 & 0.0006 & 0.0007 & 0.002 & 0.000666667 \\
\hline Bagumbayan, Malalag & 0.00018 & 0.0011 & 0.0015 & 0.00278 & 0.000926667 \\
\hline Balasinon, Sulop & 0.00044 & 0.0006 & 0.002 & 0.00304 & 0.001013333 \\
\hline San Isidro, Padada & 0.0005 & 0.0008 & 0.0011 & 0.0024 & 0.0008 \\
\hline Bucana, Hagonoy & 0.0033 & 0.0031 & 0.003 & 0.0094 & 0.003133333 \\
\hline Punta Biao, Digos City & 0.0035 & 0.0032 & 0.003 & 0.0097 & 0.003233333 \\
\hline Tagabuli, Sta. Cruz & 0.0014 & 0.0013 & 0.0011 & 0.0038 & 0.001266667 \\
\hline GRAND TOTAL & & & & 0.04085 & \\
\hline GRAND MEAN & & & & & 0.001512963 \\
\hline \multicolumn{6}{|c|}{ Analysis of Variance (ANOVA) } \\
\hline & $\begin{array}{l}\text { Sum of } \\
\text { Squares }\end{array}$ & Df & $\begin{array}{l}\text { Mean } \\
\text { Square }\end{array}$ & $\mathbf{F}$ & Sig. \\
\hline Between Groups & .000 & 8 & .000 & 17.239 & .000 \\
\hline Within Groups & .000 & 18 & .000 & & \\
\hline TOTAL & .000 & 26 & & & \\
\hline
\end{tabular}

